\title{
Nevâbitten Muhalefete: Mütevahhid'in Muhalefetinden Erdemli Siyasal Topluma
}

Adem ÇAYLAK* Onur YILDIRIM**

From Nawabit to the Opposition: From the Opposition of the Mutevahhid to the Virtuous Political Society

Citation/C): Çaylak, Adem \& Yıldırım, Onur, (2020). From Nawabit to the Opposition: From the Opposition of the Mutevahhid to the Virtuous Political Society, Milel ve Nihal, 17 (2), 333-359.

Abstract: In this study, contrary to classical or modern political philosophy, which is accepted to be good, happy and competent only in a political society, Ibn Bajjah claims that the philosopher/individual can be happy and competent on his own, "self-management of the individual" (based on the conceptualization of the rule of man alone). The possibility of transformation through the opposition of the nawabit to an unvirtuous political society will be discussed. Actually, the concept (nawabit) is negatively considered (especially in Al-Farabi) as an unvirtuous individual in a virtuous political society in the tradition of Islamic moral and political philosophy. However, the study is based on Ibn Bajjah's conceptualization of nawabit, which gives a positive meaning to the concept of "nawabit" in a degraded and distorted state. It aims to make an analysis on the praxis of how an unvirtuous political society can evolve with the opposition of the nawabit class. As a result, this study can make a theoretical contribution to the transformation of an unvirtuous state and society to the virtuous one that based on good, right, just and virtue through the analysis of the Ibn Bajjah's approach and conceptualizations, which are thought to have an exceptional place in classical political philosophy. In this context, a new opposition approach and theory can be built. Moreover, it is thought that it may seek a door towards the construction of its strategy.

Keywords: Ibn Bajjah, Nawabit, Opposition, Virtuous individual, Virtuous political society.

* Prof. Dr., Kocaeli Üniversitesi, Siyaset Bilimi ve Kamu Yönetimi Bölümü [ademcaylak@gmail.com] ORCID: 0000-0001-2345-6789.

** Dr., Kırıkkale Üniversitesi, Siyaset Bilimi ve Kamu Yönetimi Bölümü [onur20082008@hotmail.com] ORCID: 0000-0003-3946-338X. 
Atıf/C: Çaylak, Adem \& Yıldırım, Onur, (2020). Nevâbitten Muhalefete: Mütevahhid'in Muhalefetinden Erdemli Siyasal Topluma, Milel ve Nihal, 17 (2), 333-359.

Öz: Bu çalışmada, bireyin ancak bir siyasal toplum içinde iyi, mutlu ve yetkin olacağı kabul edilen klasik ya da modern siyaset felsefesinin aksine, filozofun/bireyin tek başına da mutlu olabileceği ve yetkinleşebileceği iddiasını dile getiren İbn Bacce'nin "tedbirü'l-mütevahhid" (yalnız insanın yönetimi) kavramsallaştırmasından yola çıkarak, erdemsiz bir toplumda mütevahhidin (nevâbitin) muhalefetinden erdemli bir siyasal topluma dönüşümün olanağı tartışılacaktır. Buna ilaveten çalışma, Fârâbî başta olmak üzere İslam ahlak ve siyaset felsefesi geleneğinde erdemli bir siyasal toplumda erdemsiz birey olarak olumsuz nitelendirilen "nevâbit" kavramına olumlu bir anlam yükleyen İbn Bâcce'nin nevâbit kavramsallaştırmasından yola çıkarak, bozulmuş ve çarpık bir devlette, nevâbit taifesinin muhalefetiyle erdemli bir siyasal toplumun nasıl tekevvün edebileceğinin praksisi üzerine bir analiz yapmayı amaçlamaktadır. Sonuç olarak bu çalışmanın, klasik siyaset felsefesinde istisna bir yere sahip olduğu düşünülen İbn Bâcce'ci yaklaşım ve kavramsallaştırmaların analizi üzerinden günümüzde erdemsiz devlet ve toplumunun iyi, doğru, adil ve erdeme dayanan bir dönüşümüne teorik katkı yapabileceği ve bu bağlamda yeni bir muhalefet yaklaşımı, teorisi ve stratejisinin inşasına yönelik bir kapı arayabileceği düşünülmektedir.

Anahtar Kelimeler: İbn Bâcce, Nevâbit, Muhalefet, Erdemli birey, Erdemli siyasal toplum.

\section{Giriş}

Siyasal düşünceler tarihinde Antik Yunan'dan Doğu ve İslam siyaset düşünce geleneğine, Antik Roma'dan modern siyaset düşüncesine kadar siyaset felsefesinin yanıt aradığı sorulardan birisi, "erdemli birey/ler mi erdemli siyasal toplumu (devleti) oluşturur yoksa erdemli devlet mi erdemli birey/ler meydana getirir" sorusudur. Bu soru, siyaset felsefesinin erdem-mutluluk ilişkisi çerçevesinde ortaya attığı birey-filozof-toplum-devlet ilişkisinin doğasını ve karakterini belirleyen sorudur. Kadim siyasal düşünce, insanî yetkinleşmenin ve mükemmelleşmenin (kemâle ermenin) yolunun şehir düzeyinde toplaşma ve birleşmenin vuku bulduğu siyasal toplumdan (polis/civitas perfecta/medine-i fâzıla) geçtiği yönünde bir tasavvur üzerine kuruludur. Kadim siyasal filozofların neredeyse tamamı, bi- 
Nevâbitten Muhalefete: Mütevahhid'in Muhalefetinden Erdemli Siyasal Topluma reyin ancak siyasal toplum içinde iyi olabileceğini, erdem ve yetkinlik kazanacağını düşünmüştür. Aristoteles'in zoon politikon, ${ }^{1}$ Farabi'nin medeniyyün bi't-tab² şeklinde formüle ettiği bu perspektifte insan, özü ve doğası gereği toplumsal ve siyasal bir hayvandır/canlıdır (hayevan anlamında). Böylesi bir tasavvurda, insanın temel amacı mutluluktur. ${ }^{3}$ Mutlu olmak, iyi yaşamaktır. Mutluluk ise erdeme uygun etkinlikte bulunmaktır. İnsanın mutluluğu elde etmesi, yani erdemli olması için en yetkin siyasal toplum olan devlete ihtiyacı vardır. Siyasal toplumun erdemli olması, erdemli bireylerden müteşekkil olması ile, böylelikle devletin de erdemli olacağı varsayılır ki, devleti erdemli hale getirecek olan da erdemin ne olduğunu bilen filozoftur. Bu yüzden, filozof erdemli devletin yönetim kademesinde yer alması gereken kişidir. Buradan yola çıkarak büyük oranda Platon mührü taşıyan klasik siyaset felsefesi kadar, Aydınlanma düşüncesinin ürünü olan modern siyaset felsefesinin de devletin yetkin, yani erdemli olmasıyla toplumun ve içinde yaşayan bireylerin de erdemli olacağı görüşünde olduğunu belirtmek gerekir.

Platon, erdemli olmayan devlette erdemli birey olarak yaşaminı sürdüren Sokrates'in hazin sonunu hatırasında canlı tutarak, birey-devlet ilişkisi açısından devletten yola çıkarak çözüm önerisini sunmuştu. Platon, Devlet adlı eserinin yedinci kitabının başında, ${ }^{4}$ mağaranın dışına çıkartılarak, aydınlatılan eski tutsağın, toplumsal sorumluluk sahibi bir birey (filozof) olarak mağaraya geri dönmesi ve diğer tutsakları hakikatin bilgisinin mağaranın dışında olduğuna ikna etmeye çabalamasıyla nasıl ölüme mahkûm edildiği konusunu işler. Bu durumda, akıl gücüne sahip, ancak devlet gücünden yoksun olan erdemli birey, toplumu erdemli hale getirmeye kalkıştığında, yetkinliğin, erdemin, mutluluğun, tüm bunları içine alacak şekilde hakikatin ne olduğunu bilmeyen veya bilmek istemeyen "mağaradakiler" tarafından öldürülme riskini göze almalıdır.

1 Aristoteles, Politika, çev. Furkan Akderin (İstanbul: Say Yayınları, 2. Baskı, 2015), 26.

2 Fârâbî, El-Medinetü'l Fâzıla, çev. Ahmet Arslan (Ankara: Divan Kitap, 7. Baskı, 2015), 97.

3 Mutluluk konusuna tahsis edilmiş iki temel eser için bk. Aristoteles, Nikomakhos'a Etik, çev. Saffet Babür, (Ankara: BilgeSu Yayıncılık, 8. Baskı, 2018); Fârâbî, Tahsîlu's-Sa'âda, çev. Ahmet Arslan, (Ankara: Divan Kitap, 4. Baskı, 2015).

4 Bk. Platon, Devlet, çev. Sabahattin Eyüpoğlu-M. Ali Cimcoz, (İstanbul: Türkiye İş Bankası Kültür Yayınları, 39. Baskı, 2019), 231-234. 
Bu tür bir senaryodan kaçınmak için Platon ya filozofu kral ya da kralı filozof yapma önerisini getirir.

Peki tüm filozoflar erdemli devletten hareketle erdemli bireyler meydana getirileceğini mi düşünürler? Erdemli devletin erdemli bireyler oluşturacağını göz ardı etmemekle birlikte, yaşadığı çağda erdemli devletin var olmadığı düşüncesinden hareketle "erdemli bireyi merkeze" alan İbn Bâcce, alternatif siyasal bir projenin düşünülmesi için kapı aralar.

İbn Bâcce, Eski Yunan ve İslam klasik siyaset felsefesi geleneğinde neredeyse tek başına bir paradigma kırılışının ve sapmanın filozofudur denilirse yeridir. Klasik siyaset felsefesi geleneğinde bireyin ancak siyasal toplumla yetkinleşebileceği düşüncesinin aksine İbn Bâcce, siyasal toplum erdemsiz hale geldiğinde mütevahhid bir bireyin tek başına yetkinleşebileceği, iyi ve erdemli olabileceği tasavvuru üzerinden erdemli tek başına bireylerden (mütevahhidlerden) müteşekkil bir erdemli siyasal topluma ulaşılabileceğinin felsefesini yapmaktadır. Burhana (kanıtlara dayalı akıl yürütme) dayalı felsefe geleneğinin, diğer adıyla Meşşâî felsefi geleneğin Endülüs'te bilinen ilk temsilcisi olan İbn Bâcce, erdemli bireyden erdemli devlete intikalin ana hatlarını ortaya koyar.

Bu çalışmanın konusunu, "tedbirü'l-mütevahhid" teorisi bağlaminda İbn Bâcce'nin ileri sürdüğü erdemsiz siyasal topluma muhalif, garip, sıra dışı ve toplum dışı nevâbit taifesinden müteşekkil filozof/bireyden yola çıkarak erdemli siyasal topluma intikal projesi oluşturmaktadır. Bu çalışmada, İslam siyasal düşünce geleneğinde kimi düşünürler tarafından kavramsallaştırılan nevâbit terimine İbn Bâcce'nin yüklediği anlam üzerinden bir muhalefet praksisi oluşturma ve böylelikle erdemli bireylerden müteşekkil bir siyasal topluma geçişin mümkün olup olmadığı tartışılacaktır. Bu girişim denemesi, İbn Bâcce'nin Tedbirü'l-Mütevahhid isimli eserinin odak noktası üzerinden gerçekleştirilecektir. Bu çerçevede, erdemsiz şehirde "ayrıksı ot" anlamina gelen "muhalif", "aykırı" ve "huzursuz" ancak yalnızlığın yönetimi üzerinden erdem, iyi, doğru ve adaleti arayan "münzevi", "garip" ve "güreba" taifesinden olan nevâbit birey(ler)den müteşekkil bir erdemli siyasal toplum arayışının imkânları aranacaktır. Bu perspektifte ayrıntıları aşağıda açıklanacağı üzere çalışmanın nihai amacı, İbn Bâcce'nin nevâbit kavramına yüklediği anlamdan yola çıkarak erdemli bireylerden müteşekkil 
Nevâbitten Muhalefete: Mütevahhid'in Muhalefetinden Erdemli Siyasal Topluma

bir muhalefet praksisinin olanağını tartışmak ve günümüzde erdemsiz toplumlarda bozulan birey-siyasal toplum ilişkisine ne tür katkılarda bulunulabileceğini çözümlemektir.

Sözlüklerde, dünya umur ve ahvalinden habersiz, olgunlaşmamış, pişmemiş taze delikanlı ve fidanı imlemek bakımından "bitkiler" ve "ayrık otu" anlamına gelen nevâbit (tekili, nabite) terimi, ${ }^{5}$ İslam siyasal düşünce geleneğinde siyasal toplum (şehir/site) içinde hakikati toplumun dışında sınırlarda ve kenarlarda arayan taifeyi kavramsallaştırmak amacıyla kullanılmıştır. İslam siyasal düşünce tarihinde nevâbit terimi ilk kez el-Cahız tarafından kullanır. Cahız, Risale li'l-Cahız fi Beni Ümeyye ${ }^{6}$ eserinde nevâbit terimini, siyasal firkaları ifade etmek için kullanır. Cahız, Kitabu Halki'l Kur'an adlı eserinde, Kur'an'ın mahlûk olduğunu iddia edenlerin nevâbit olarak isimlendirildiğini belirtir. ${ }^{7}$ Cahız'da, nevâbit teriminin, hâkim görüşten sapma gösterenler ve genel anlayıştan farklı düşünenler için kullanıldığı anlaşılmaktadır.

İslam siyaset felsefesinde nevâbit terimini olumsuz anlamda ilk kullanan filozof Fârâbî' dir. Fârâbî için nevâbit, erdemli şehirdeki erdemsiz kişilerdir. Fârâbî, istenmediği halde ortaya çıkan, erdemli şehri (siyasal toplumu) bozan, huzurunu kaçıran nevâbit taifesini dokuz sınıfta tasnif eder. Fârâbî'nin tasnifinde, fırsatçılar (mutâkannisûn), tahrif ediciler/yanlış yorumlayanlar (el-muharrife), dinden çıkanlar (el-mârika) olarak adlandırılan ilk üç sınıf, nevâbit taifesinin en olumsuzları olup, niyetleri bozuk olanlardır. Diğer altı sınıf ise niyetleri iyi olduğu halde şehir için iyiyi hayal etmelerine rağmen, hayal ettikleri hakkında tam bir kanıya sahip olmayan, hayal ettikleri her şeyin yanlış olduğunu gösteren, yeterli derecede tasavvur gücüne sahip olmayan, hakikati anlayanı küçük görerek hakikati yanlış saymak isteyen, hakikati herkese nasıl görünüyorsa öyle sanan, arzu ettikleri şeyleri gerçek amaçlar olarak gören kimselerden müteşekkildir. Fârâbî, ilk üç sınıf başta olmak üzere, şehrin

5 Bk. Mütercim Âsım Efendi, Kâmûsu'l-Muhit Tercümesi, el-Okyânuŝsu'l-Basit fi̊ Tercemeti'l-Kâmusisi'l-Muhit, der. Mustafa Koç ve Eyyüp Tanriverdi (İstanbul: T.C. Yazma Eserler Kurumu Başkanlığı Yayınları, 1. Baskı, 2013).

6 Bk. el-Cahız, "Emevi İdaresi Üstüne”, çev. Yüksel Macit, Hikmet Yurdu 1/2 (Temmuz-Aralık 2008): 213-231.

7 Ali Ebu Mülhim, "Mukaddimetü Amme”, Resaill'l-Cahız, s. 37'den aktaran, Osman Aydınlı, "Mu'tezile Geleneğinin Kur'an-1 Kerim Tasavvuru", İslami İlimler Dergisi 1/1 (Bahar 2006): 51. 
amaçları ile örtüşmediğini düşündügü türedi nevâbit taifesinin erdemli şehrin yöneticisi tarafından devamlı izlenmesi, meşgul edilmesi, onları tedavi edecek özel yöntemler uygulanması ve gerekiyorsa şehirden kovulması, hapsedilmesi ya da angarya ve zor işlerde çalıştırılması gerektiğini ifade eder. ${ }^{8}$

Bireyin (tezhibü'l ahlak), ailenin (tedbirü'l menzil) ve toplumun (tedbirü'l mudûn) yönetimi olarak siyaset, Farabi'den sonra İslam ahlak ve siyaset felsefesi üzerine yazan Nasîrüddin Tûsi'nin Ahlâk-ı Nasır̂̂, Celaleddin Devvani'nin Ahlâk-ı Celalı̂ ve Kınalızâde'nin Ahlâk-ı Alâı̂'sinde aynı biçim ve içerikte ele alınıp incelenmiştir. Bu çerçevede erdemli şehirde ortaya çıkan erdemsizleri imleyen nevâbite olumsuz yaklaşım, sayılan eserlerde hemen hemen Fârâbi'deki gibidir. Örneğin Kınalızâde, devlet yönetimi (tedbirü'lmudûn) bahsinde, erdemli devletin bilincine varan toplumun erdemli saydığı beş tabakasını (fazıllar, dilciler, değer biçenler, gaziler/mücahitler ve mal sahipleri) sıraladıktan sonra, bu beş grubun dışında olanları, aynen Fârâbî' de olduğu gibi nevâbit olarak nitelendirir ve devletin ana sütunlarının dışında görür. Kınalızâde, bunların fazilet kazanacak yetenekleri varsa kalifiye işte çalıştırılmalarını, eğer yoksa devletteki beş iş kolunda kullanılmaları gerektiğini ifade etmek suretiyle nevâbite ilişkin olumsuz imgeyi şu sözleriyle tasvir eder:

Bu beş grubun dışındakilere "nevâbit" denir. Erdemli devlet, içinde elma ve üzüm gibi meyveli ağaçlar, güzel çiçekler, selvi ve çınar gibi süs ağaçları, bahçe duvarı olmaya yarayan meyvesiz dikenli ağaçlar ve süslü sergi misali taze yeşillik bulunan bir bahçeye benzer. Bahçede mutlaka kendiliğinden biten faydasız bitkilerin de bulunması ve bahçıvanın onları bulup dışarı atması gerekir. Aynı şekilde erdemli şehrin d1şında kalan bu topluluk da faydasızdır. Devlet başkanı onları kovup uzaklaştırmaya çalıştığı için bunlar "nevâbit" diye adlandırılmıştır. ${ }^{9}$

Nevâbit taifesini riyakârlar, tahrifçiler, asiler, yoldan çıkanlar ve yanıltanlar olarak beş gruba ayıran Kınalızâde, bunlarla birlikte

8 Fârâbî, es-Siyâsetü'l-Medeniyye veya Mebâdi'ül-Mevcûdât, çev. Mehmet S. Aydın, Abdülkadir Şener ve M. Rami Ayas (İstanbul: Büyüyenay Yayınları, 3. Baskı, 2017), 122-127.

9 Kınalızâde Ali Çelebi, Ahlâk-ı Alâî, sad. Murat Demirkol (Ankara: Fecr Yayınları, 1. Bask1, 2016), 421-422. 
Nevâbitten Muhalefete: Mütevahhid'in Muhalefetinden Erdemli Siyasal Topluma nevâbitin bundan çok olduğunu belirtip, bunların toplum ve yönetimde haksızlık, gasp ve yalancılık yapan polis ve zabıtalar, rüşvet alan kadılar, ilmini satan müderrisler, sömüren sipahiler, dolandırıcılar ve dilencilik yaparak halka yük olan zavallılar olduğunu ifade eder. Ona göre, bu grupların tamamı nevâbit nev'inden addedilmelidir. Erdemli devletin başkanının onları idam etmesi ya da sürgüne göndermesi vaciptir. ${ }^{10}$

Görüldüğü gibi başta Fârâbî olmak üzere, ondan sonra bu konuda yazan düşünürlerin çoğunda nevâbit, erdemli şehrin marjinal ve azınlık erdemsizleri olarak nitelendirilirken, kavram ilk defa İbn Bâcce'de olumlu bir içerime sahip olacaktır. İbn Bâcce'de nevâbit, erdemsiz devletten erdemli devlete geçişte önemli rol oynayan, bir tür toplumun vicdanını temsil eden ve sayıca az olan birey ya da birey topluluğuna karşılık gelmektedir. İşte bu da nevâbit taifesinin, yerleşik bozulmuş düzene itaat etmemesi, toplumun içinde bedenen yaşasalar bile zihnen ve kalben toplumun yaygın çarpık değerlerine karşı durması, gerekirse sınırda yaşaması ve olmuyorsa o toplumu terk edip doğurgan ve üretken bir inziva sürecine girmesi ve nevâbit üzerinden bir muhalefet praksisi geliştirmesiyle, erdemsiz devleti erdemli siyasal topluma dönüştürmede derinden etkisinin olabileceğini düşündürtmektedir.

\section{Erdemli Birey: Nevâbit /Mütevahhid}

Tedbirü'l-Mütevvahid adlı eser, İbn Bâcce'nin siyasetle ilgili görüşlerinin neredeyse tamamını ihtiva eder. ${ }^{11}$ İbn Bâcce, bu eserde, erdemli olmayan devlette yaşamını sürdüren filozofun, insanın temel amacı olan mutluluğu, tek başına elde etmesi için nasıl bir yol izlemesi gerektiğini ana hatlarıyla ortaya koyar. ${ }^{12}$ Fakat İbn Bâcce, Meşşâi felsefi geleneği takip etmek suretiyle “doğası gereği siyasal bir varlık olan insanın, doğal mükemmelliği, en yüce iyiyi, başka bir deyişle mutluluğu ancak siyasal toplum" vasıtasıyla elde edeceğinin de farkındadır. Bu yüzden İbn Bâcce'nin asıl siyasal projesi, erdemli olmayan devletin erdemli bireyi olan filozofun tek başına mutluluğu nasıl elde edeceğiyle ilgili değildir.

\footnotetext{
10 Kınalıâde Ali Çelebi, Ahlâk-ı Alầ, 423-424.

11 Yaşar Aydınlı, İbn Bâcce'nin Insan Görüşü, (İstanbul: Marmara Üniversitesi İlâhiyat Fakültesi Vakfı Yayınları, 1. Baskı, 1997), 254.

12 Michael E. Marmura, "The Philosopher and Society: Some Medieval Arabic Discussions", Arab Studies Quarterly 1/4 (Fall 1979): 317.
} 
İbn Bâcce, erdemli olmayan devletin erdemli bireyini ifade etmek için eserinde çoğunlukla mütevahhid kavramını kullanır. Aslına bakılırsa mütevahhid, erdemsiz şehirde yaşayan ancak toplumun kusurları ve erdemsizliklerinden azade olan nevâbit taifesinden olan filozof/yetkin/erdemli bireyi imler. İbn Bâcce, mütevahhidin nev-i şahsına münhasır duruşunu sergilemek amacıyla onun erdemli olmayan devlette yaşayan bir müfred (yalnız) veya aynı anlama gelecek şekilde garip, said (mutlu insan) ve nabit (nevâbit) olduğunu ifade eder. İbn Bâcce'nin mütevahhid için önerdiği bu değişik adlandırmaların tamamını sırasıyla tahlil etmek gerekiyor. Çünkü kelime anlamı itibariyle birbirinden farklı çağrışımlara sahip olan bu adlandırmaların tamamı mütevahhidin şahsında erir.

İbn Bâcce, mütevahhidin, erdemli olmayan devletin erdemli bireyi olarak bir müfred (yalnız, tek kişi) veya garip olduğunu belirtir. ${ }^{13}$ Onun için tecrit, maddeye tutkun ruhların mesken edindiği erdemli olmayan toplumdan kaçışın tek yoludur. ${ }^{14} \mathrm{Bu}$ yüzden mütevahhid, kendi vatanında, arkadaşları ve komşuları arasında olsa dahi benimsediği farklı görüşlerden dolayı gariptir. ${ }^{15} \mathrm{Bu}$ bağlamda, İbn Bâcce'nin nevâbit taifesinden olan mütevahhidi, bir bakıma Oğuz Atay'ın yerleşik toplumun yaygın kabul edilen iki/çok yüzlü ortak ve genel tutum ve değerlerine ayak uyduramayan Tutunamayanlar'ına benzer. ${ }^{16}$ "Tutunamayanlar", yalnızdır, sıra dışıdır, beğeni, kariyer, güç ve para peşinde koşmayan, değerleri ve ilkeleri menfeatlere satmayan, kitlenin genel halet-i ruhiye ve davranış koduna sahip olmayan, hep itilip kakılan, hor görülen ancak farklı görülerinden dolayı marjinal ve muhalif olup toplumun anlaşılmayan vicdanlı ve erdemli birey(ler)idir.

En yüce amaç olan mutluluğu hedefleyen mütevvahhidin madde ile bir ilgisi bulunamaz. ${ }^{17}$ Mütevahhidin bilinçli bir şekilde kendini toplumdan tecrit etmesi, yani içinde yaşadığı topluma yabancılaşması kendi mutluluğu için zorunludur. İbn Bâcce, mütevvahidin kendini toplumdan tecrit etmesini (bedenen olmasa bile

13 İbn Bâcce, Tedbîrü'l-Mütevahhid, çev. Mevlüt Uyanık-Aygün Akyol (Ankara: Elis Yayınları, 3. Bask1, 2019), 30-32.

14 Erwin I. J. Rosenthal, Ortaçă̆'da İslâm Siyaset Düşüncesi, çev. Ali Çaksu (İstanbul: İz Yayıcılık, 1. Baskı, 1996), 251.

15 İbn Bâcce, Tedbîrü'l-Mütevahhid, 30.

16 Oğuz Atay, Tutunamayanlar (İstanbul: İletişim Yayınları, 99. Baskı, 2019).

17 Henry Corbin, İslâm Felsefesi Tarihi Cilt 1, çev. Hüseyin Hatemî (İstanbul: İletişim Yayınları, 11. Baskı, 2017), 402. 
zihnen ve kalben) müfred mertebesine ulaşmasını said (mutlu insan) olmasının ön koşulu olarak sunar. Bu bakımından, İbn Bâcce'de madde ile akıl arasında taban tabana zitlık durumu söz konusudur. İnsan, kendisini maddeden tamamen soyutladığında, akli, yani erdemli ve ilahi olacak; böylelikle de mutluluğu elde edecektir. ${ }^{18}$

Erdemli devlette kendiliğinden ortaya çıkan mütevahhid, bilinçli bir şekilde yalnız kalmayı tercih eden bireye işaret eder. Toplumun fikir ve görüşlerini benimsemeyen mütevahhid, bu yönüyle nevâbit adını almaya hak kazanır. ${ }^{19}$. İbn Bâcce, Fârâbî’den ödünç aldığı nevâbit kavramını, onun kavramı kullandığı bağlamdan farklı bir bağlam içinde kullanmayı tercih eder. İbn Bâcce, erdemli devletin tüm sakinleri doğru bilinç ve eylem üzerine oldukları, dolayısıyla da onlar arasında görüş ayrılıkları olmayacağı için orada nevâbitin ortaya çıkmasının mümkün olmadığını ifade eder. ${ }^{20}$

İbn Bâcce ile birlikte nevâbit, gül bahçesinde kendiliğinden türeyen zararlı otlardan, bir bahçıvanın özenine muhtaç olmadan kırda kendiliğinden yetişen otlara dönüşür. ${ }^{21}$ Dolayısıyla nevâbit taifesinden olmak, doğadan geldiği gibi olmaktır. Bozulmuş siyasal toplumun kültüründen neşet etmiş çarpıklık ve yapaylı̆̆a mahkûm olmamak için toplumun kenarlarında yaşamayı, doğallığı içinde göze alan nevâbit, var olan bozulmuş ve kokuşmuş yerleşik düzene ve statükonun kirliliklerine meydan okuyarak kendiliğindeliğini kuran insana denir. Başka bir deyişle nevâbit, var olan bozulmuş siyasal toplumda zan ve yanlıştan beslenen ortak kanaatler ve inançlara, genel geçer değerlere ve kötülük ile sıradanlaşmış ortak anlayış ve yaşayışların karşısında ahlak, adalet, hakkaniyet ve erdem arayan insanın temiz kalarak bir tür direnişini simgeler.

Câbirî̀ye göre, İbn Bâcce nevâbit kavramını, erdemli olmayan toplumun inzivaya çekilmiş bireyleri için kullanır. Filozofun hayatta olduğu dönemdeki devletler erdemli olmadığg için, bu devletlerde nâbit sıfatını alanlar erdem ve üstünlük bakımından yalnız kalmış bireylerdir. ${ }^{22}$ Nevâbit taifesinden olan mütevahhid, toplumun içindeki doğru ve erdemli “öteki”dir. Toplumun marjlarında

\footnotetext{
18 İbn Bâcce, Tedbîrü'l-Mütevahhid, 104.

19 İbn Bâcce, Tedbîrü'l-Mütevahhid, 30.

İbn Bâcce, Tedbîrü'l-Mütevahhid, 30.

21 M. Saeed Sheikh, Islamic Philosophy, (London: The Octagon Press, 1982), 122.

22 Muhammed Âbid el-Câbirî, Felsefi Mirasımız ve Biz, çev. A. Said Aykut (İstanbul, Kitabevi, 2003), 195.
} 
yaşayan nevâbit, sınırları belirlenmiş, beslenmiş ve sulanmış bahçenin ekini (kültürü) değildir. Elle yetiştirilmeye çalışılan bahçenin bozulmuş bir bitkisi olmayan nevâbit, kendi doğallığı içinde sınırları belirlenmiş alanın dışında toplumun sınırında doğal kendiliğindenliğin erdemini temsil eden ayrıksı ottur. Bu haliyle çarpık ve iğdiş olmuş düzene, iyi, doğru ve erdem adına meydan okuyan muhalif tabiatlı nevâbitin yeri yurdu sinırsızlıktır. Böylelikle İbn Bacce'de nevâbit, erdemli olmayan şehirlerin toplumuna karışmayan ve onların kötülüklerine bulaşmaktan kaçınan sınırda ve kenarda yaşayanları ifade etmek için kullanılarak kavrama olumlu bir içerim kazandırılmıştır.

İbn Bâcce'nin erdemli olmayan devletin erdemli bireyi mütevahhidi ifade etmek üzere kullandığı bu kavramların tamamı, mütevahhidin şahsında birleşir. Bu kavramlar, mütevahhidin durumunu izah etmek için iç içe geçmiş kavramlardır. Mütevahhid, erdemli olmayan devlette yaşayan bir müfred, garip, nevâbit ve saiddir. Bu haliyle mütevahhid, "kendi kendinin yönetimine" odaklanmak zorundadır. İbn Bâcce, mütevahhidin "kendi kendini yönetimine", "tedbirü'l-mütevahhid" adını verir. Aslında bir addan fazlası olan bu terkip, erdemli olmayan devletin erdemli bireyinin mutluluğu için ortaya atılan bir teori veya strateji olarak görülmelidir.

\section{Erdemli Bireyin Yönetimi: “Tedbirü'1-Mütevahhid”}

İbn Bâcce, Fârâbî'nin siyaset felsefesi ekolüne bağlı Endülüslü ilk filozof olarak bilinir. ${ }^{23}$ Hatta Câbirî, felsefi sistemi büyük oranda Fârâbî'ye dayanan İbn Sina'nın ahlak ve siyaset alanıyla ilgilenmediğini gerekçe göstererek, Fârâbî'nin bu alandaki ilk önemli takipçisinin İbn Bâcce olduğunu ifade eder. ${ }^{24}$ Benzer bir şekilde Fakhry, İbn Bâcce'nin siyasal terminoloji ve siyasal sistemlerle ilgili analizi bakımından Fârâbî'den istifade ettiğini belirtir. ${ }^{25}$ Masumi'ye göre, İbn

23 Steven Harvey, “İbn Bâcce: Bireyin Kendi Kaderini Tayin Hakkı”, İslam Felsefesinde Siyasi Düşüncenin Gelişimi, ed. Charles E. Butterworth, çev. Selahattin Ayaz (İstanbul: Pınar Yayınları, 1. Baskı, 1999), 172.

24 Muhammed Âbid el-Câbirî, Arap Ahlaki Aklı, çev. Muhammet Çelik (İstanbul: Mana Yayınları, 2. Baskı, 2016), 464.

25 Majid Fakhry, Islamic Philosophy, Theology and Mysticism: A Short Introduction (Oxford: Oneworld Publications, 1997), 88. 
Nevâbitten Muhalefete: Mütevahhid'in Muhalefetinden Erdemli Siyasal Topluma

Bâcce, felsefi sistemi ve araştırmaları için her ne kadar farklı bir yöntem benimsemiş olsa da, ${ }^{26}$ Tedbirü'l-Mütevahhid adlı eserinde kullandı̆̆ı en dikkat çekici siyasal kavramları Fârâbî’den ödünç alır. Goodman da İbn Bâcce'nin, Fârâbî'nin, "Platoncu siyaset ve Aristotelesçi ahlakın İslamileştirilmiş bir versiyonu ile Yeni-Platoncu ilahiyat arasında kurduğu sentezin farkında" olduğunu ifade eder. ${ }^{27}$ İbn Bâcce, bu sentezin ortaya koyduğu en yetkin çıktı olarak "insanın temel amacının mutluluk olduğu" ilkesini görür. ${ }^{28}$ Üstelik Fârâbî gibi, İbn Bâcce için de insan doğası gereği siyasal bir varlıktır. ${ }^{29}$ İbn Bâcce, Aristoteles mührü taşıyan, ondan da Fârâbî'ye ve Meşşâî felsefe geleneğine bağlı diğer filozoflara intikal eden bu görüşü paylaşır.

Bununla birlikte, İbn Bâcce'yi Fârâbî' den ayıran ${ }^{30}$ ve siyaset felsefesi açısından onun özgünlügüunün kanıtı olan husus, erdemli olmayan devletin erdemli bireyinin mutluluğu nasıl elde edeceği ve muhafaza edeceği üzerine düşünmüş olmasında yatar. İbn Bâcce, Fârâbî'nin erdemli olmayan devletin erdemli insanının mutlu olma

M. Saghir Hasan Masumi, "Ibn Bajjah on Human Intellect", Islamic Studies 4/2 (June 1965): 121.

27 Lenn E. Goodman, "İbn Bâcce", İslâm Felsefesi Tarihi, ed. Seyyid Hüsseyin NasrOliver Leaman, çev. Şamil Öcal-Hasan Tuncay Başoğlu (İstanbul: Açlım Kitap, 2017), 358.

28 İbn Bâcce, Aristotelesçi mutluluk anlayışına takip eder. Bu anlayışa göre, doğadaki her varlık gibi insan da elde ettiğinde mutlu olacağı bir amacı gerçekleştirmek üzere yaratılmıştır. İnsanın amacını gerçekleştirmesi, onun son yetkinlik durumunda olduğunun işaretidir. O halde insan, son yetkinliği ulaştığında, amacını gerçekleştirmiş, dolayısıyla mutluluğu elde etmiştir. İbn Bâcce için insanın mutluluğu, kendine özgü en temel işlevi olan aklın kılavuzluğunda eylemde bulunmasıdır. Bk. Aristoteles, Nikomakhos'a Etik, 205.

29 Zerrin Kurtoğlu, İslâm Düşüncesinin Siyasal Ufku (İstanbul: İletişim Yayınları, 2. Baskı, 2013), 157.

30 Câbirî́ye göre, İbn Bâcce'nin Fârâbî’ den ayrılışı epistemolojik düzlemdedir. Bu ayrılış, Maşrık kaynaklı İslam felsefesinin yoğunlaştığı konuları ihmal etme anlamına gelir. İbn Bâcce, Ortaçağ felsefesinin en çok üzerine yoğunlaştığı din ve felsefeyi uzlaştırma projesinin bir parçası olmamıştır. O, daha sonra İbn Rüşd ile evrensel bir öğreti halini alacak olan "dini, kendi ölçütleriyle, felsefeyi de yine aynı şekilde kendi ölçütleriyle ele alma" projesine giden yolu açmışır. Câbirî, İbn Bâcce'nin bu ihmalinin bilinçli bir tercih olduğunu ve sadece ayn ilkelerden doğan birkaç farklı bakış tarzından ibaret olmadığını ifade eder. Ona göre, İbn Bâcce' nin felsefi tutumu, Maşrık kaynaklı İslam felsefesinin epistemolojik temellerinden tamamen kopma anlamina gelir. Bu yüzden onun felsefi tutumunu, "epistemolojik kopma" olarak adlandırmak yerinde olacaktır. Bk. Câbirî, Felsefi Mirasımiz ve Biz, 206. 
imkânına sahip olmadığ1 yönündeki görüşünü kabul etmez. ${ }^{31}$ Zira İbn Bâcce erdemli devlette "her insana doğasına uygun en yüksek mükemmelliğin" sunulduğunu ifade etmek suretiyle bu devletin çatısı altında yaşamını sürdüren tüm insanların doğru görüşe sahip olduğunu belirtir. ${ }^{32}$ Erdemli devletin sakini olan tüm insanların görüşleri doğru ve eylemleri erdemli olduğu için "tek bireyin mutluluğu siyaset biliminin konusu olamaz." 33 O halde, tek bireyin mutluluğu siyaset biliminin konusu haline getirilecekse, bu ancak erdemli olmayan devletin erdemli bireyinin varlığıyla söz konusu olur. İbn Bâcce bu öncülden hareketle insanın temel amacı olan mutluluğu ancak toplum içinde ve erdemli devlette elde edeceği şeklindeki "Aristoteles kaynaklı İslam siyasal düşünce geleneğine, bu geleneği külliyen reddetmeksizin alternatif bir yaklaşım geliştirir." 34 İbn Bâcce' ye göre, erdemli olmayan devletin erdemli bireyinin, yani mütevahhidin stratejisi "bireysel yönetim" olarak adlandırılan "tedbirü'l-mütevahhid" olmalıdır.

İbn Bâcce tedbiri, "eylemlerin belirli bir amaca yönelik olarak düzenlenmesi" olarak tanımlar. Ancak burada altı çizmemiz gereken nokta, tedbirin özel bir amacı gerçekleştirmek üzere tek bir eylemde bulunan birine uygulanamayacak olmasıdır. Tedbir için etkinliğin "birden fazla eylemden oluşması ve bir düzene" sahip olması gerekir. ${ }^{35}$ İbn Bâcce tedbiri bu şekilde tanımladıktan sonra, onu dört türe ayırır. Bunlardan ilki mutlak bir tedbir olan Allah'ın evreni tedbiridir. İkincisi, devletle ilgili tedbirdir. Tedbir kelimesiyle mutlak olarak kast edilen anlam bu tedbir olsa da, İbn Bâcce tedbirin bu türüyle ilgili detaylı bir açıklama yapmaksızın, okuyucuyu Platon'a yönlendirir. Ona göre, tedbirin üçüncü türünü evin tedbiri oluşturur. Tedbirin dördüncü türünü "tedbirü'l-mütevahhid" oluşturur. ${ }^{36}$ İbn Bâcce'nin yeni şeyler söylemek istediği tedbir türü budur. O, erdemli olmayan toplumda yaşamını sürdüren erdemli bireyin, yani mütevahhidin tedbiriyle ilgilenir.

31 Burhan Köroğlu, “İbn Bâcce'nin Ahlak ve Siyaset Düşüncesi”, Divan (1996/1): 65.

32 İbn Bâcce, Tedbîrü'l-Mütevahhid, 28.

33 Kurtoğlu, İslâm Düşüncesinin Siyasal Ufku, 159.

34 Köroğlu, "İbn Bâcce'nin Ahlak ve Siyaset Düşüncesi”, 49.

35 İbn Bâcce, Tedbîrü'l-Mütevahhid, 18.

36 İbn Bâcce, Tedbîrü'l-Mütevahhid, 18-20. 
Nevâbitten Muhalefete: Mütevahhid'in Muhalefetinden Erdemli Siyasal Topluma

Mütevahhid, erdemli olmayan toplumun erdemli yalnız bireyidir. Mütevahhid, sufilerin "garip" olarak adlandırdıkları kişilerdendir. Onlar her ne kadar kendi yurtlarında, komşuları arasında ve evlerinde olsalar da savundukları görüş itibariyle gariptirler. Toplumun geri kalanından farklı görüş benimsedikleri için zihni ve davranış olarak vatan haline getirdikleri başka mertebelere hicret etmişlerdir. ${ }^{37}$ İşte mütevahhid, bir insan olarak kendisini doğasına aykırı bir ortamda bulduğu için toplumla diyalogunu sona erdirir. Ancak o aynı zamanda bir filozof olduğu için temel amacı olan mutluluğu elde etmekten vazgeçemez. Bu yüzden, mütevahhidin tedbiri elden bırakmaması gerekir. Mütevahhidin tedbiri, bireyi belli bir amaca götürecek olan etkinliği oluşturan eylemlerin düzenlenmesi anlamına gelir. ${ }^{38} \mathrm{Bu}$ amaç, hiç şüphesiz doğasını koruyan bir insan ve bir filozof olarak mutluluğu elde etmektir. Mütevahhid mutluluğu elde etmek için kendini erdemli olmayan toplumdan tecrit ederek, kendi içine hicret eder.

Bu stratejiyle erdemli olmayan toplumun erdemli bireyi, yani cahil kalabalıklar arasında yalnız kalan bir filozof olarak mütevahhid mutluluğu elde eder. Zaten İbn Bâcce için mütevahhid, hakiki mutluluğun ne olduğu bilen kişidir. Onun bu mutluluğu elde etmesi için ihtiyaç duyduğu tek şey akıl yetisidir. ${ }^{39} \mathrm{O}$, faal akılla ittisal aşamasında kazandığı bilgiyle mutluluğu elde eder. Başka bir deyişle, mütevahhidin faal akılla ittisali halinde elde ettiği bilgi, mutluluğun bizzat kendisidir. ${ }^{40}$

İlk bakışta paradoksal görünen, insanın doğası gereği siyasal bir varlık olduğu ve toplumsal tecridin kötü olduğu önermeleri, İbn Bâcce tarafından birbiriyle uyumlu hale getirilir. Şöyle ki, İbn Bâcce tecridin özü bakımından kötü olduğunu kabul eder. Ancak tecrit, pek çok şeyde olduğu gibi, ilineksel olarak gerçekleşirse iyi olabilir. ${ }^{41}$ Söz gelimi, afyon özü gereği öldürücü bir zehir olduğu için kötüdür. Ancak afyon, bedenin hastalığa yakalandığı durumlarda olduğu üzere, ilineksel olarak faydalı olabilir. Kuşkusuz öldürücü bir

\footnotetext{
37 İbn Bâcce, Tedbîrü'l-Mütevahhid, 30.

Kurtoğlu, İslâm Düşüncesinin Siyasal Ufku, 161.

9 Oliver Leaman, "İbn Bâcce'nin Toplum ve Felsefeye Bakışı”, çev. Bayram Tamtürk, Bozok Üniversitesi Ilahiyat Fakültesi Dergisi [BOZIFDER] 15/15 (2019/15): 219.

40 Sheikh, Islamic Philosophy, 119.

41 Fakhry, Islamic Philosophy, Theology and Mysticism: A Short Introduction, 89.
} 
zehrin, beden için faydalı olduğu durumlar istisnaidir. Ancak beden, doğasına aykırı olan hastalık durumlarında öldürücü bir zehirden medet umabilir. Bu analojiyi, devlete uygulayacak olursak, erdemli devlet, mükemmel, bozulmamış siyasal rejime verilen addır. Doğası gereği siyasal bir varlık olan insan da bu devlet sayesinde temel amacı olan mutluluğu elde eder. ${ }^{42}$ Ancak devletin özüne aykırı bir şekilde erdemli olmadığı durumlarda, doğası gereği siyasal bir varlık olan insan, bireysel mutluluğu için toplum ile olan diyalogunu kesme mecburiyetindedir. Çünkü İbn Bâcce'ye göre, erdemli olmayan devlet, insanın doğasına aykırıdır. ${ }^{43}$ İşte İbn Bâcce, erdemli olmayan devlette yaşamını sürdüren erdemli bireyin, en azından bireysel mutluluğunu garanti altına alması için “tedbirü'1 mütevahhid"i bir strateji olarak ortaya koyar.

Ne var ki, İbn Bâcce tarafından erdemli bireyin, bireysel mutluluğu elde etmesi ve koruması amacıyla ileri sürülen bu strateji, filozofun gayrı siyasal bir tavır almasını gerektirmez. Çünkü erdemli devletin oluşumu, mutluluğa sahip olan filozofun, toplumun diğer mensuplarını bu mutluluğa ortak etmesine bağlıdır. ${ }^{44}$ İşte İbn Bâcce' nin mütevahhide yüklediği siyasal rol tam olarak burada başlar. Bir insan olması hasebiyle doğası gereği toplumsal-siyasal bir canlı olan mütevahhid, erdemli olmayan devlette yine kendi doğasını korumak gibi bir idealin peşinden giderek, siyasal kimliğinden vazgeçer göründüğü bir anda, siyasal bir misyonu kendisine ödev olarak belirler. ${ }^{45}$. İbn Bâcce, mütevahhidin gayrı siyasal bir izlenim yaratan duruşundan hareketle önemli bir siyasal rolü onun omuzlarına yükler: Erdemli siyasal toplumun inşası!

Mütevahhidin siyasal rolüne geçmeden önce, epistemolojik aç1dan onu diğer canlı varlıklardan ayıran dayanağın ne olduğunu belirlemek gerekir. İbn Bâcce'nin siyaset felsefesi, mütevahhidin epistemolojik kaynağı olarak adlandırabileceğimiz unsura dayalıdır. ${ }^{46}$

42 Mahmut Kaya, İslâm Filozoflarından Felsefe Metinleri (İstanbul: Klasik, 3. Bask1, 2005), 423.

43 İbn Bâcce, Tedbîrü'l-Mütevahhid, 128.

44 Oliver Leaman, An Introduction to Classical Islamic Philosophy (Cambridge: Cambridge University Press, 2nd Edition, 2002), 187.

45 Kurtoğlu, İslâm Düşüncesinin Siyasal Ufku, 170.

46 Harvey, "İbn Bâcce: Bireyin Kendi Kaderini Tayin Hakk1", 180. 


\section{Mütevahhidin Siyasal Eyleminin Kılavuzu: Tanrısal Akıl}

İbn Bâcce, eylemin niteliğinin eylemi gerçekleştiren varlığın doğasına ve türüne göre belirlendiğini ifade eder. ${ }^{47}$ Varlık türleri sırasıyla, cansızlar, bitkiler, hayvanlar ve insanlar olmak üzere dörde ayrılır. Cansız varlıkların eylemleri taşın düşmesi, ateşin yükselmesi gibi eşyanın doğasından kaynaklanan zorunlu eylemler kategorisine girer. ${ }^{48}$ Bitkisel varlıkların eylemleri ise, beslenme, üreme ve büyüme gibi canlı tabiatın zorunlu işlevlerinin yerine getirilmesini içeren eylemlerdir. ${ }^{49}$ Bitkisel varlıklar, canlı varlık âleminin en alt tabakasını oluşturan varlıklardır. ${ }^{50}$ Hayvanlar ise, cismani bir varlığa sahip olmaları nedeniyle cansız varlıklarla zorunlu eylemler kategorisine giren şeyler açısından ortak olmakla birlikte, hayvani nefislerinden kaynaklanan içgüdüsel eylemlerinden dolayı onlardan ayrılırlar. ${ }^{51}$ Sira insana gelince, İbn Bâcce, onun cisim, ruh ve akıldan oluştuğunu ifade eder. ${ }^{52}$ Başka bir deyişle insan, cismani (büyüme, beslenme ve üreme yetilerini kapsayan suretler), özel ruhani (ortak duyu, hayal etme ve hatırlama yetilerini kapsayan suretler) ve genel ruhani (akıl yetisini kapsayan suretler) olmak üzere üç ayrı suretten müteşekkildir. O halde insandan çıkan tüm eylemler ya cismani doğasından ya sadece canlılık tabiatına ait içgüdüsel yönünden ya da akıl sahibi olmasından dolayı kendisinden doğan eylemlerdir. ${ }^{53}$

İbn Bâcce'ye göre, bu üç eylem türünden sadece akli eylemler, mütevahhidin tedbiriyle ilgilidir. Bu yönüyle insan, zorunlu ve içgüdüsel eylemler bakımından cansız varlıklar, bitkiler ve hayvanlarla ortak bir doğaya sahip olmasına rağmen, iradi ve ihtiyari eylemleri meydana getiren akıl yetisinden dolayı bu üç varlık türünden ayrılır. ${ }^{54}$ Determinist bakış açısıyla doğayı bir zorunluluk alanı olarak gören İbn Bâcce, insanın akıl yetisiyle bu alana özgü ilişkileri

\footnotetext{
Köroğlu, “íbn Bâcce'nin Ahlak ve Siyaset Düşüncesi”, 53.

Câbirî, Arap Ahlaki Aklı, 471.

İbn Bâcce, Kitâbu'n-Nefs, çev. Mevlüt Uyanık-Aygün Akyol-Bayram Tamtürk (Ankara: Elis Yayınları, 1. Baskı, 2020), 36-54.

Aydınlı, İbn Bâcce'nin İnsan Görüşü, 135.

İbn Bâcce, Kitâbu'n-Nefs, 134.

İbn Bâcce, Tedbîrü'l-Mütevahhid, 34.

İbn Bâcce, Tedbîrü'l-Mütevahhid, 40.

Leaman, An Introduction to Classical Islamic Philosophy, 188.
} 
aşabileceğini belirtir. ${ }^{55} \mathrm{O}$, Risaletü'l-Veda adlı risalesinde, aklın, insana Allah tarafından bahşedilen en değerli hediye, en sevimli şey olduğunu ifade eder. ${ }^{56}$

Diğer taraftan İbn Bâcce, akıl sahibi bir canlı olan insanın kendisinden doğan tüm eylemlerin, tedbirin konusu olamayacağına da dikkat çeker. Bu noktada İbn Bâcce'nin insan için yukarıdaki suretler ayrımını benimsemiş olmakla birlikte, insanı temelde cisim ve ruhtan oluşan bir varlık olarak değerlendiren Helenistik görüşü takip ettiğini ifade etmek gerekir. Bilindiği üzere, insanın cismani yönü tamamen nedensellik kanununa bağlı olduğundan onun bu yönü ile hür bir varlık olduğu söylenemez. İnsanın ruhani yönünü ise, "duygusal hayatı ile akli hayatı" oluşturur. ${ }^{57} \mathrm{O}$ halde, insanın ruhani yönünden hareketle onun eylemlerini iki kısma ayırmak mümkündür. İlki, İbn Bâcce'nin özel ruhani suretler adını verdiği duygusal hayatına bağlı olan eylemlerdir. Bu eylemler, kaynağı itibariyle ilham gibi insanın kendinden geçiş anlarında ortaya çıkan eylemlerdir. İlham, sezgi ve mistik aydınlanma gibi gnostisizim kaynaklı bu tür eylemler akıl dışı oldukları veya akıl tarafından tarif edilemedikleri için tedbirin konusu olamazlar. ${ }^{58} \mathrm{Bu}$ yüzden İbn Bâcce, Risaletü'l-Veda adlı risalesinde Gazalî'yi eleştirerek, onun inziva ve uzlet durumunda insanın tanrısal nur vasıtası ile ruhani ve manevi evreni müşahede etmek suretiyle mutluluğa ulaşacağı önerisini kabul etmez. ${ }^{59} \mathrm{O}$ halde, eylemlerin tedbirin konusu olabilmeleri için, onların özgür irade ve tefekkür gücü ile ortaya çıkmaları gerekir.

Bu yönüyle siyasal eylemin, mütevvahidin tedbirine uygun bir eylem olarak değerlendirilmesi gerekir. Zira hatırlanacağı üzere, mütevahhid için genel ruhani suretler amaç konumdaydılar. $\mathrm{O}$ halde soralım: Genel ruhani suretlerin amaç olması ne anlama gelir? En kestirme yoldan bu soruya verilecek yanıt mütevahhidin tikellerin değil, tümelin bilgisinin peşinde olduğudur. Özel ruhani suretin

55 Mustafa Yıldız, “Yalnızlığın Felsefesi: İbn Bâcce' de Filozofun Yabancılaşması Sorunu", Felsefe Dünyası 55 (2012/1): 103.

56 Kaya, İslâm Filozoflarından Felsefe Metinleri, 432.

57 Aydınlı, İbn Bâcce'nin İnsan Görüşü, 18.

58 Burhan Köroğlu, "İbn Bâcce ve İbn Tufeyl: Felsefe Endülüs'te”, İslâm Felsefesi Tarih ve Problemler, ed. M. Cüneyt Kaya (İstanbul: İsam Yayınları, 1. Baskı, 2013), 337.

59 T. J. de Boer, İslâm'da Felsefe Tarihi, çev. Yaşar Kutluay (İstanbul: Anka Yayınları, 3. Bask1, 2001), 214. 
Nevâbitten Muhalefete: Mütevahhid'in Muhalefetinden Erdemli Siyasal Topluma yetileri olan ortak duyu, hatırlama ve hafıza ancak tikelleri algılama gücüne sahipken, genel ruhani suretin yetisi olan akıl tümelin bilgisini amaç edinir. ${ }^{60}$

İbn Bâcce'nin temelde insani eylemleri izah etmek için kullandığı bu ifadelere siyasal bir anlam kazandırmak istersek, iki farklı yorum getirebiliriz: İlki, erdemli olmayan devletler sayıca birden fazla olmasına rağmen, erdemli devlet bir ideal olarak tektir. Mütevahhidin amacı tekin ve tümelin bilgisine erişmek olduğu için onun peşinde koşacağı siyasal ideal erdemli devletin bilgisidir. İkincisi, İbn Bâcce'nin bir rasyonalist olarak mütevahhidin eylem alanını aklın kılavuzluğuna bırakmış olmasıyla ilgilidir. Buna göre İbn Bâcce, Platon'un siyasal görüşlerine sadık kalan Fârâbî, İbn Sina ve İbn Rüş̧'ün tersine, erdemli devletin sadece nebevî bir yasa koyucu tarafından ortaya çıkarılacağı görüşünü dile getirmez. $\mathrm{O}$, erdemli olmayan devlette akıl yetisini kullanmak suretiyle ahlaki ve zihni mükemmelliğe ulaşmış bir ya da birkaç kişinin erdemli devleti ortaya çıkarma imkânından söz eder.

Bu iki farklı yorum aynı noktada buluşur: Erdemli olmayan devletten erdemli devlete intikal için önce erdemli bireyin var olması gerekir. Bu intikali gerçekleştirecek olan erdemli olmayan devletin erdemli bireyi/nevâbiti, yani mütevahhiddir.

\section{Mütevahhidin Siyasal Misyonu: Erdemli Olmayan Devleti Dönüştürme}

İbn Bâcce, "tedbirü'l-mütevahhid" teorisiyle erdemli bireyi toplumdan tecrit ederken, onu aynı zamanda siyasal toplum idealinden tecrit etmez. Onun, mütevahhidi tecrit ettiği toplum insanın temel amacına ulaşmasını engelleyen, bu yüzden de insan doğasına aykırı olan bir toplumdur. ${ }^{61}$ Dolayısıyla İbn Bâcce, bir taraftan mütevahhid dışında erdemli tek bir insanın dahi bulunmadığ zaruri işler dışında kendisini toplumdan tecrit etmesi gerektiğini ifade ederken, diğer taraftan da mütevahhiddin k1lavuzluğunda siyasal topluma, yani erdemli devlet idealine ulaşılabileceğini ima etmekten geri durmaz.

Zira İbn Bâcce açısından bir insan olarak mütevahhidin toplumla diyalogunu kesmesi ne başlı başına bir hedef ne de doğal bir

\footnotetext{
60 Aydınlı, İbn Bâcce'nin Insan Görüşü, 116.

61 Kurtoğlu, İslâm Düşüncesinin Siyasal Ufku, 171.
} 
eylemdir. ${ }^{62}$ Mütevahhidin, ideallerini hayata geçirebileceği bir ortam arayışında olması, hatta idealleri için hicreti dahi göze alması, onun siyasal topluma duyduğu güçlü isteğin belirtisidir. ${ }^{63}$ İbn Bâcce, mütevahhidin fiziksel ihtiyaçlarını karşılayabilmesi için toplumsal hayata ontolojik anlamda bağlı olduğunu kabul etmekle birlikte, onun erdemli olmayan devletin siyasal koşullarına teslim olmasını tercih etmez. Zaten mütevahhidin söz konusu siyasal koşullara teslim olması, onun erdemli olmayan devletin erdemli bireyi olma özelliğini kaybetmesi ve siyasal toplum idealinden vazgeçmesi anlamina gelir. Bu ise, erdemli olmayan devletin erdemli devlete intikali için ontolojik bir zorunluluğa sahip olan mütevahhide uygun olan siyasal tavır alış olamaz. Çünkü mütevahhid, erdemli olmayan devlette kendiliğinden ortaya çıkan nevâbit olarak erdemli görüş ve eylemlere sahip olan kişidir. ${ }^{64} \mathrm{O}$ halde, burada yanıt aranması gereken soru mütevahhidin ilk bakışta gayri siyasal izlenim veren, ancak özü gereği siyasal olana yönelen eylem türü ile neyi amaçladığıdır. Çünkü İbn Bâcce'nin "tedbirü'l-mütevahhid” teorisinde, Fârâbî'nin ifadesi ile "henüz kurulmamış" olan erdemli devletin ${ }^{65}$ oluşumuna yönelik bir amacın gizli olduğunu belirtmek gerekir. ${ }^{66}$

Leo Strauss'a göre, her tür siyasal eylemin amacı ya muhafaza etme ya da değiştirme ilkesi üzerine kuruludur. Eğer siyasal eylem ile muhafaza etme amaçlanıyorsa daha kötüye doğru bir değişim engellenmek istenir. Tam tersine, siyasal eylemin amacı değiştirme ise, daha iyi bir siyasal düzeni meydana getirme arzusu hâkimdir. O halde, her siyasal eyleme daha iyi ve daha kötü düşüncesi kıla-

62 İbn Bâcce, bunun başlı başına bir hedef ve doğal bir eylem olmadığını şu ifadeleriyle aktarır: "O insanın (mütevahhidin) başına doğasının dışında bir iş gelmiştir." Bk. İbn Bâcce, Tedbîrü'l-Mütevahhid, 32. Aydınl, İbn Bâcce'nin İnsan Görüşü, 304.

64 Ilai Alon, “Farabi's Funny Flora Al-Nawabit as “Opposition”, Arabica 37/1 (Mar. 1990): 87.

65 Câbirî, erdemli devletin varlığı bakımından Fârâbî ile İbn Bâcce'nin birbirinden farklı pozisyonlara sahip olduğunu ifade eder. Ona göre, Fârâbî, Maşrık'ta Seyfüddevle'nin himayesi altında erdemli devlet rüyası görmekteydi. Başka bir deyişle, erdemli devletin kuruluşu için gerekli olan şartlar ortaya çıkmıştı. Diğer taraftan, İbn Bâcce'nin içine doğduğu Endülüs'te erdemli devlet rüyası görmek için henüz çok erkendi. Bu yüzden Câbirî, İbn Bâcce'nin mütevahhid için tasarladığı tedbiri, "erdemli devletin ilk tuğlası"olarak görür. Bk. Câbirî, Arap Ahlak Akl, 465.

66 Aydınlı, İbn Bâcce'nin İnsan Görüşü, 279. 
Nevâbitten Muhalefete: Mütevahhid'in Muhalefetinden Erdemli Siyasal Topluma vuzluk eder. Ancak, "daha iyi veya daha kötü düşüncesi her halükârda iyi düşüncesini" ima eder. Çünkü siyasal eylem ile amaçlanan muhafaza etmek olduğunda, daha kötünün engellenmesi, dolayısıyla da iyi anlayışının muhafaza edilmesi söz konusudur. Siyasal eylem değiştirmeyi amaçladığında ise, amaç daha iyiye ulaşmak olduğu için yine iyi anlayışı söz konusudur. ${ }^{67}$ Buna göre, her türlü siyasal eylemin amacı iyiye ulaşmaktır. Strauss'un rehberliğinde, İbn Bâcce'nin sahneye sürdüğü mütevahhide oynatmak istediği siyasal role bakıldığında, onun erdemli olmayan devlet içinde yaşamakla birlikte, bu devletin siyasal koşullarını kabul etmediğini iddia etmek yanlış olmayacaktır. O halde, mütevahhidin siyasal eyleminin amacı muhafaza etmek olamaz. Elde kalan tek seçenek, mevcut siyasal koşulları değiştirmektir. Strausscu anlamda mevcut siyasal düzenin "daha iyi” için değiştirilmesidir. Peki mütevahhid bu değiştirme işlemini nasıl gerçekleştirecektir?

İbn Bâcce, erdemli devletin ne a priori (deney öncesi) var olduğunu ne de siyasal bir ihtilal sonucu erişebilir olduğunu ifade eder. ${ }^{68}$ İbn Bâcce, mütevahhid ve ona katılacak olan diğer erdemli bireylerin varlığının erdemli devletin ortaya çıkma nedeni olduğunun "başka yerlerde" açıklandı̆̆ını söylemekle yetinir. ${ }^{69} \mathrm{O}$ halde soralım: İbn Bâcce "başka yerler" ile kendine ait diğer çalışmaları mı yoksa diğer filozofların çalışmalarını mı kast etmektedir? Marmura, İbn Bâcce'nin “başka yerler” ile Platon'un Devlet adlı eserinin beşinci kitabını kast ettiğini ileri sürer. ${ }^{70}$ Gerçekten de Platon, söz konusu eserin beşinci kitabının son sayfalarını erdemli devletin kurulmasının mümkün olup olmadığı sorusuna ayırır. Platon yanıt aradığı bu soruyla ilgili iki seçenek ortaya koyar: İlki, erdemli devletin, ideal devlet olmasıyla ilgilidir. Platon, bu devleti şu metafor üzerinden anlatır: "Bir ressam en kusursuz ve güzel insan resmini çizmesine rağmen, böyle bir insanın olabileceğini kanıtlamaya gücü yetmezse, bundan ötürü ressamın değeri azalmaz". O halde, bu devleti kurmanın mümkün olmaması, onun değerini kaybedeceği anlamina gelmez. ${ }^{71}$ Diğer taraftan Platon ikinci seçeneğiyle, ideal devlet

67 Leo Strauss, Politika Felsefesi Nedir, der. ve çev. Solmaz Zelyüt (İstanbul: Öteki Yayınevi, 1. Bask1, 2017), 40.

68 Corbin, İslâm Felsefesi Tarihi Cilt 1, 400.

69 İbn Bâcce, Tedbîrü'l-Mütevahhid, 30.

70 Marmura, "The Philosopher and Society: Some Medieval Arabic Discussions", 318.

71 Platon, Devlet, 181. 
tasarısından tamamen vazgeçmemesine rağmen, bu tasarıdan taviz vermeyi kabul eder. Buna göre, ideal devlete en fazla benzeyen devletin kurulması, ideal devletin kurulabileceğinin işaretidir. Bunun için mevcut devletlerin hangi kusurlarından ötürü ideal devlet gibi yönetilmediklerini tespit edip, yapılacak küçük bir değişiklikle onları ideal devlete yaklaştırmak gerekir. Peki ne tür bir değişiklikle, mevcut devletler ideal devlete yaklaşacaklardır? Başka bir şekilde sormak gerekirse, Platon'un ideal devlete en yakın devlet olarak gördüğü devlet hangi devlettir? Farklı şekillerde ifade edilen bu iki sorunun tek bir yanitı vardır: Filozof-kral. ${ }^{72}$

İbn Bâcce'nin, Platon'un ortaya koyduğu bu iki seçenekten hangisine daha yakın olduğunu anlamanın yolu, Tedbirü'l-Mütevahhid başlıklı esere başvurmaktan geçer. İbn Bâcce, bu eserde, erdemli devlet kuramı geliştirme çabası içerisinde değildir. Bu yüzden, İbn Bâcce'nin Platon'un ilk seçeneğine rağbet etmeyeceğini söylemek mümkündür. O halde, elde tek bir seçenek kalmaktadır: Mevcut devleti, erdemli devlete dönüştürmek. Platon'un bu dönüşüm için önerisi ya filozofu kral ya da kralı filozof yapma şeklindeydi. Ancak İbn Bâcce ne filozofun kral ne de kralın filozof yapılmasını mevzu bahis eder. Hatta erdemli olmayan devletin erdemli bireyinin mutluluğu için, eğer varsa erdemli bir devlete hicret etmesi gerektiğini bir seçenek olarak sunar. ${ }^{73}$ İşte tam bu nokta, bizi Platon'un ikinci seçeneğini takip etmeye sevk eden, ancak Platon takibini bir yere kadar sürdürdükten sonra sona erdiren İbn Bâcce'nin özgün siyasal projesini başlattığı noktadır. İbn Bâcce, erdemli olmayan devleti erdemli devlete dönüştürme noktasında Platon'un yöntemine sadık kalmaz. Onun siyasal projesinde, aydınlanmış, hakikatin bilgisini elde eden, akıl gücüyle devlet gücünü şahsında toplayan, böylelikle de tepeden-inmeci bir şekilde erdemli devleti meydana getiren filozof-krala yer yoktur. Ona göre, erdemli olmayan devlette mütevahhid, toplumun kendisini daha iyi anlayabileceği bir zamana kadar yeteneklerini koruma altına almalı ya da gelecekte toplumsal

72 Platon, Devlet, 181-182.

73 İbn Bâcce, Tedbîrü'l-Mütevahhid, 128. 
Nevâbitten Muhalefete: Mütevahhid'in Muhalefetinden Erdemli Siyasal Topluma ortamın iyileşeceği umuduyla öğrendiklerini başkalarına aktarmalıdır. ${ }^{74}$ Câbirî'nin deyişiyle, erdemli devleti oluşturabilecek çoğunluğa ulaşıncaya kadar "yalnız başına" var olan bireyler kendilerini bireysel olarak en iyi şekilde gerçekleştirmelidirler. ${ }^{75}$

İbn Bâcce'nin siyasal projesinde, mütevahhidin öncülük pozisyonu değişmemekle birlikte, yukarıdan aşağı bir dönüşüm değil, aşağıdan yukarı bir dönüşüm ortaya çıkmaktadır. Başka bir deyişle, mütevahhidin temsil ettiği öncülük, erdemli olmayan devlete karşı düşünce eksenli muhalefete öncülük etmektir. Bu sayede erdemli olmayan devletin erdemli hale gelmesi mümkün olacaktır. Ancak biraz evvel hızlı bir şekilde değinerek geçtiğimiz "mütevahhidin erdemli devlete hicreti" konusunu açmak gerekir.

İbn Bâcce, mütevahhidin mutluluğu için ilim ehliyle arkadaş olması gerektiğini belirtir. Ona göre ilim ehli bazı hayat tarzlarında az, bazılarında çok, bazılarında ise yok denecek kadar azdır. Bu nedenle, mütevahhidin bazı hayat tarzlarında mümkün olduğunca kendini insanlardan tecrit etmesi, zaruri işler dişında onlarla ilişkiyi kesmesi, eğer varsa ilmin bulunduğu erdemli devlete hicret etmesi gerekir. ${ }^{76}$ İbn Bâcce, mütevahhidin erdemli devlete hicreti konusunu detaylı bir şekilde anlatmaz. Ancak görünen o ki, İbn Bâcce, mütevahhidin erdemli devlete hicreti meselesini iki koşula ontolojik olarak bağlar. İlki, mütevahhidin ilim ehlinin az, hatta yok denecek kadar az olduğu bir toplumda yaşaması koşuludur. İkincisi, hicret edilebilecek erdemli bir devletin var olması koşuludur. İbn Bâcce, bu ikinci koşul özelinde "eğer varsa" ifadesini kullanmak suretiyle bir anlamda hicretin olanaksızlığını anlatmaya çalışır. O halde mütevahhid ne yapmalıdır? Aslında İbn Bâcce'den önce Fârâbî, bu soruyu ortaya atarak, çözüm önerisini sunmuştu. Fârâbî'nin çözümü, erdemli devletin yokluğundan dolayı hicret etme imkânı kalmayan filozof için "ölümün yaşamdan daha hayırlı" olduğu şeklindeydi. ${ }^{77}$ Ne var ki İbn Bâcce, erdemli devletin yokluğu halinde, ölümün yaşamaktan daha hayırlı olduğu şeklinde herhangi bir görüşü dile getirmez. İbn Bâcce, hicret konusuna değindiği pasajın devamında,

\footnotetext{
74 Leaman, "İbn Bâcce'nin Toplum ve Felsefeye Bakışı”, 227.

Câbirî, Arap Ahlaki Aklı, 485.

İbn Bâcce, Tedbîrü'l-Mütevahhid, 128.

77 Fârâbî, "Fusûlü'l-Medenî", Fârâbî'nin İki Eseri, çev. Hanifi Özcan (İstanbul: M. Ü. İlâhiyat Fakültesi Vakfı Yayınları No: 196, 3. Baskı, 2017), 117.
} 
mütevahhidin içine doğduğu erdemli devletten ayrılmamakla birlikte, onun yanlış uygulamalarına olur vermeden, kendi içine dönerek (hicret ederek) bireysel mutluluğu elde etmesi gerektiğini belirtir. ${ }^{78}$ Bu noktada İbn Bâcce, mütevahhidin mutluluğu, erdemli olmayan devleti tamamen terk ederek, İbn Tufeyl'in roman kahramanı Hayy bin Yakzan gibi insanlardan uzak bir adada tek başına elde edebileceği yönünde de bir imada bulunmaz. ${ }^{79}$ Mütevahhid, faal akılla ittisal halinde olarak zihinsel düzeyde hicretini gerçekleştirebilir. $\mathrm{O}$, bu hicret sayesinde bireysel mutluluğu elde eder.

Ne var ki, İbn Bâcce açısından bireysel mutluluk, en yüce mutluluk anlamına gelmez. Çünkü tedbir gerektiren işlerin en şereflisi aile ve devlet yönetimidir. ${ }^{80}$ Zihinsel düzeyde hicret etmek suretiyle bireysel mutluluğu elde eden mütevahhid, sahip olduğu yetkinlik sayesinde bu mutluluğu aile ve devlet düzeyinde de gerçekleştirmelidir. Burada temel soru şudur: Mütevahhid, bu mutluluğu aile ve devlet düzeyine nasıl taşıyacaktır? Tek başına, içe hicret etmek suretiyle en azından bireysel mutluluğu elde eden mütevahhidin bu mutluluğu genişletmesinin yolu nedir? İbn Bâcce'nin önerisi, erdemli olmayan devlette yaşayan mütevahhidin kendisi gibi olanlarla birleşmesi yönündedir. Ona göre, "ideal düzeyde ahlaki ve akli mükemmelliğe ulaşan mütevahhidin bu durumunu gören diğer akıl ve erdem sahipleri ona katılırlar." ${ }^{81}$ Bu katılım, fiziki düzeyde bir araya gelmekten ziyade zihinsel düzeyde bir ortaklık gerçekleştirme şeklindedir. Böylelikle ortak bir düşünce seviyesine ulaşan tüm bu bireyler, tek bir vücut gibi hareket ederler.

O halde, İbn Bâcce, doğal mükemmelliği için kendini erdemli olmayan toplumdan tecrit eden mütevahhidin zamanı geldiğinde erdemli olmayan devleti erdemli devlete dönüştürmek için siyasal eylemde bulunması gerektiğini ima etmez mi? Marmura, İbn Bâcce'nin bunu ima ettiğini, onun "tedbirü'l-mütevvahid" teorisinin bu şekilde yorumlanması gerektiğinin doğal ve makul olduğunu belirtir. Ona göre, İbn Bâcce'nin mütevvahhidi ile içinde yaşadığı Antik Atina Polis'ine "yabancı" olmakla birlikte, onu erdemli hale getirmek için toplumsal-siyasal reformun gerekliliğine vurgu

78 İbn Bâcce, Tedbîrü'l-Mütevahhid, 128.

79 Bk. İbn Tufeyl, Hayy bin Yakzân, çev. Babanzâde Reşid, haz. Hacer Sevim Aydoğdu (İstanbul: Büyüyenay Yayınları, 3. Baskı, 2019).

80 İbn Bâcce, Tedbîrü'l-Mütevahhid, 20.

81 İbn Bâcce, Tedbîrü'l-Mütevahhid, 128. 
Nevâbitten Muhalefete: Mütevahhid'in Muhalefetinden Erdemli Siyasal Topluma yapan Sokrates arasinda benzerlikler bulunur. ${ }^{82}$ Nasıl ki Sokrates, önce "kendini bil" ilkesiyle bireyden hareketle toplumsal-siyasal reforma giden yolu açmış ise, İbn Bâcce'de erdemli olmayan devlette erdemli bireyin nasıl mutlu olabileceği sorusuna yanıt aramak üzere geliştirdiği "tedbirü'l-mütevahhid" teorisiyle, son tahlilde erdemli bireyden erdemli devlete intikalin mümkün olduğunun yolunu açar.

Şöyle ki, mütevahhidin bir filozof olarak mutluluk idealinden vazgeçmeyişi öncülüyle, bir insan olarak siyasal bir varlık olduğu öncülünü, birbiriyle mas ederek tek bir öncül haline getirdiğimizde, erdemli bireyden erdemli devlete intikalin imkânı söz konusu olur. Yani, "doğası gereği siyasal bir varlık olan filozof-insanın temel amacı mutluluktur" öncülü erdemli devletin oluşumuna imkân verir. O halde, mütevahhid için öngörülen tedbir, "henüz kurulmamış", ancak kurulması mümkün olan erdemli devlette uygulanacak olan tedbirin prototipini oluşturmaktadır. ${ }^{83}$ Yani İbn Bâcce, erdemli devleti, mütevahhidin özlem duyduğu ${ }^{84}$ veya Spinozacı insani eylem kategorisinden yararlanmak gerekirse arzuladığı (cupiditas) devlet olarak görür.

\section{Sonuç}

İbn Bâcce'nin erdemli bireyden erdemli devlete intikal konusunda ana hatlarını ortaya koyduğu siyasal projesinde, idealleri ile realitenin (çağının siyasal koşullarının) çatışmasını görmek mümkündür. İbn Bâcce, bir taraftan mütevahhid aracilığıla sembolize ettiği nevâbitlikte ideallerini, diğer taraftan da mütevahhidi içine yerleştirdiği erdemli olmayan devletle realiteyi tasvir eder. Zira İbn Bâcce, bir filozof olmasının yanında, geçiş döneminde (söz konusu dönemde, Mağrib ve Endülüs'te aynı anda var olan iki devlet bulunmaktaydı: İbn Haldun'un deyişiyle "ihtiyarlık dönemine girmiş" Murabıtlar Devleti ile kültürel ve siyasal anlamda varlığını kabul ettirmeye çalışan Muvahhidler Devleti) yaşayan bir devlet adamıdı. Bir filozof olması nedeniyle ideallerinden vazgeçmezken, bir devlet adamı olması nedeniyle de realiteden kopamazdı. Bu yüzden, İbn Bâcce, bağlı olduğu felsefi gelenekten tamamen kopmadan,

82 Marmura, "The Philosopher and Society: Some Medieval Arabic Discussions", 318.

83 Aydınlı, İbn Bâcce'nin İnsan Görüşü, 287.

84 Yıldız, "Yalnızlığın Felsefesi: İbn Bâcce'de Filozofun Yabancılaşması Sorunu”, 121. 
alternatif bir yaklaşım benimser. Kuşkusuz, insanın temel amacı olan mutluluğu elde etmesi için erdemli devletin varlığı zorunludur. Ancak İbn Bâcce, Meşşâi felsefi geleneğin siyasal öğretisinin aksine, filozofu erdemli devletin yönetim kademesine yerleştirmek suretiyle devletten hareketle erdemli bireylerden müteşekkil bir toplum arayışı içerisine girmez. Erdemli olmayan toplumda yaşayan erdemli bireyin kendi hayat tarzına ve araştırma konularına yoğunlaşarak bireysel mutluluğu elde etmesi için bir teori ortaya koyar.

İbn Bâcce'nin "tedbirü'l-mütevahhid"ini gerçekleştireceğini düşündüğü ve erdemsiz bir toplumda erdemliler olarak tasvir ettiği nevâbit taifesi, bugünkü siyasal ve toplumsal gerçeklik için ne anlam ifade etmektedir? Siyasal toplumların neredeyse tamamının erdemsiz hale geldiği, adaletsizliğin, hakkaniyetsizliğin, vicdansızlığın ve kötülüğün hâkim olduğu günümüz toplumlarında İbn Bâcce'nin nevâbit taifesi üzerinden bir erdemli muhalefet teorisi ve praksise dayalı bir muhalefet stratejisinin ortaya çıma potansiyeli üzerine düşünmek gerekmektedir. Nevâbit kaynaklı bir muhalefet teori ve pratiğinin potansiyelini harekete geçirmek, erdemli birey(ler)in erdemsiz toplumdan kendilerini tecrit etmesi ile imkân dâhiline girebilecektir. Bunun için nevâbit taifesinin yani erdemsiz toplumda erdemli bireylerin, var olan, yerleşik ve statükoya dayalı siyasal topluma yabancılaşmaları oldukça önemli bir başlangıç noktasıdır. Tecrit ve yabancılaşma, sadece ilgili toplumda yaşamamak ve erdemsiz toplumu terk etmek anlamına gelmemektedir. Nevâbit taifesi erdemsiz toplumun içinde ya da sınırlarında yaşayan genel kitle psikolojine uyumsuz ve kötülüklerden huzursuz bireyler olarak öncelikle kötü toplumun erdemsiz değerleri karşısında zihinsel bir tecrit içinde bilişsel ve düşünsel aşamadan geçecektir. Başka bir deyişle, cismani ve özel ruhani suretlerin (öfke gücü ve arzu gücü) hâkimiyetinden ziyade genel ruhani suretlerin hâkimiyetindeki aklın gücünün bireye hâkim olması, klasik siyaset felsefesinin terimleri ile ifade etmek gerekirse, cesaret (öfke gücü), iffet (arzu gücü) ve hikmet (akıl gücü) dengesinde bireyi dolayısıyla siyasal toplumu adalete sevk edecektir.

Nevâbitin zihinsel ve psikolojik tecridi olmadığında davranışsal tecrit ya da hicretinin değeri olmayacaktır. Erdemsiz ve kötülüklerin hâkim olduğu toplumda nevâbit, bir tür yalnızların ve "tutunamayanların" bilişsel ve davranışsal perspektifini haiz olacaktır. Bunun için nevâbitin var olan devletin siyasal koşullarını bilişsel 
Nevâbitten Muhalefete: Mütevahhid'in Muhalefetinden Erdemli Siyasal Topluma olarak reddetmesi ve yerleşik siyasal toplumda hâkim olan oyunun kuralları ile hareket etmemesi elzemdir. Uyrukluğun hâkim olduğu erdemsiz toplumda nevâbit, "uygunsuz" hareket ederek erdemsiz toplumun üzerine oturduğu değer ve ilkeleri yapı sökümüne uğratacaktır. Bu da "tutunamayanların" yoludur.

İbn Bacce'nin sınırda yaşayan, huzursuz ve uyumsuz nevâbit taifesinden oluşan erdemli bireylerin düşünsel ve davranışsal tecrit ve soyutlamasının ete kemiğe bürünmesi, günümüz siyasal toplumunun kuralları çerçevesinde işlevsellik kazanan ve gün geçtikçe tıkanan muhalefet teori ve pratiğine katkı sağlayacaktır. Sadece reddetme, şiddet ya da oyunun kuralları bağlamında işleyen muhalefet kültürü ancak kendi bindiği dalı kesecek ve iktidar olduğunda muhalefette iken savundukları ve eylediklerinin unutulmasına yol açacaktır. Bu yüzden nevâbit taifesi üzerinden yürüyecek "tedbirü'lmütevahhid" teorisi, öncelikle bilişsel, düşünsel, yargısal ve davranışsal arınma ve tecrit ile iyi, doğru ve adalet adına sürekli işleyecek bir muhalefet teori ve pratiğini harekete geçirebilecektir. Bu duruş ve eylem nevâbit birey üzerinde kendisini üreterek ve yeniden-üreterek mümkün hale gelecektir. Çünkü her toplumsal inşa ve oluş, bozuluşa temayüllüdür. Bu döngüyü kırmanın yolu, nevâbitliğin süreklilik kazanması ile tekevvün edebilecek bir erdemli topluma dönüşüm sürecidir.

\section{Kaynakça}

Alon, Ilai. “Farabi's Funny Flora Al-Nawabit as “Opposition”. Arabica 37/1 (1990): 56-90.

Aristoteles. Politika. Çev. Furkan Akderin. İstanbul: Say Yayınları, 2015. . Nikomakhos'a Etik. Çev. Saffet Babür. Ankara: BilgeSu Yayınc1lık, 2018.

Atay, Oğuz. Tutunamayanlar. İstanbul: İletişim Yayınları, 2019.

Aydınlı, Osman. "Mu'tezile Geleneğinin Kur'an-1 Kerim Tasavvuru”. İslâmî İlimler Dergisi 1/1 (2006): 39-57.

Aydınlı, Yaşar. İbn Bâcce'nin İnsan Görüşü. İstanbul: Marmara Üniversitesi İlâhiyat Fakültesi Vakfı Yayınları Nu. 60, 1997.

Corbin, Henry. İslâm Felsefesi Tarihi Cilt 1. Çev. Hüseyin Hatemî. İstanbul: İletişim Yayınları, 2017.

De Boer, T. J. İslâm'da Felsefe Tarihi. Çev. Yaşar Kutluay. İstanbul: Anka Yayınları, 2001.

El-Câbirî, M. Âbid. Felsefi Mirasımız ve Biz. Çev. A. Said Aykut. İstanbul: Kitabevi, 2003. ları, 2016. Arap Ahlaki Aklı. çev. Muhammet Çelik. İstanbul: Mana Yayın- 
El-Cahız. "Emevi İdaresi Üstüne”. Çev. Yüksel Macit, Hikmet Yurdu 1/2 (2008): 225-244.

Fakhry, Majid. Islamic Philosophy, Theology and Mysticism: A Short Introduction. Oxford: Oneworld Publications, 1997.

Fârâbî. El-Medinetü'l Fâzıla. Çev. Ahmet Arslan. Ankara: Divan Kitap, 2015. . Tahsîlu's-Sa'âda. Çev. Ahmet Arslan. Ankara: Divan Kitap, 2015 .

Es-Siyâsetü'l-Medeniyye veya Mebâdi'ül-Mevcudat. çev. Mehmet S. Aydın, Abdülkadir Şener ve M. Rami Ayas. İstanbul: Büyüyenay Yayınları, 2017.

. Fusûlü'l-Medenî. Çev. Hanifi Özcan. İstanbul: M. Ü. İlâhiyat Fakültesi Vakfı Yayınları No: 196, 2017.

Goodman, Lenn E. "İbn Bâcce". İslâm Felsefesi Tarihi, ed. Seyyid Hüsseyin Nasr-Oliver Leaman, Çev. Şamil Öcal-Hasan Tuncay Başoğlu, İstanbul: Açılım Kitap, 2017, 341-361.

Harvey, Steve. "İbn Bâcce: Bireyin Kendi Kaderini Tayin Hakkı". İslam Felsefesinde Siyasi Düşüncenin Gelişimi, ed. Charles E. Butterworth, Çev. Selahattin Ayaz, İstanbul: Pınar Yayınları, 1999, 171-200.

İbn Bâcce. Tedbîru'l-Mütevahhid. Çev. Mevlüt Uyanık-Aygün Akyol. Ankara: Elis Yayınları, 2019.

Kitâbu'n-Nefs. Çev. Mevlüt Uyanık-Aygün Akyol-Bayram Tamtürk. Ankara: Elis Yayınları, 2020.

İbn Tufeyl. Hayy bin Yakzân. Çev. Babanzâde Reşid. Haz. Hacer Sevim Aydoğdu. İstanbul: Büyüyenay Yayınları, 2019.

Kaya, Mahmut. İslâm Filozoflarmdan Felsefe Metinleri. İstanbul: Klasik, 2005.

Kınalızâde Ali Çelebi. Ahlak-ı Alâi. Sad. Murat Demirkol. Ankara: Fecr Yayınları, 2016.

Köroğlu, Burhan. "İbn Bâcce'nin Ahlak ve Siyaset Düşüncesi". Divan (1996/1): 45-65.

. “İbn Bâcce ve İbn Tufeyl: Felsefe Endülüs'te”. İslâm $\mathrm{Fel}-$

sefesi Tarih ve Problemler, 329-364. Ed. M. Cüneyt Kaya. İstanbul: İsam Yayınları, 2013.

Kurtoğlu, Zerrin. İslâm Düşüncesinin Siyasal Ufku. İstanbul: İletişim Yayınları, 2013.

Leaman, Oliver. An Introduction to Classical Islamic Philosophy. Cambridge: Cambridge University Press, 2002.

"İbn Bâcce'nin Toplum ve Felsefeye Bakışı". çev. Bayram

Tamtürk, Bozok Üniversitesi İlahiyat Fakültesi Dergisi [BOZIFDER] 15/15 (2019/15): 217-232.

Marmura, Michael E. "The Philosopher and Society: Some Medieval Arabic Discussions". Arab Studies Quarterly 1/4 (1979): 309-323.

Masumi, M. Saghir Hasan. "Ibn Bajjah on Human Intellect". Islamic Studies 4/2 (1965): 121-136. 
Nevâbitten Muhalefete: Mütevahhid'in Muhalefetinden Erdemli Siyasal Topluma Mütercim Âsım Efendi. Kâmûsu'l-Muhit Tercümesi (el-Okyânûsu'l-Basit fin Tercemeti'l-Kâmuisi'l-Muhit). der. Mustafa Koç-Eyyüp Tanrıverdi. İstanbul: T.C. Yazma Eserler Kurumu Başkanlığı Yayınları, 2013.

Platon. Devlet. Çev. Sabahattin Eyüpoğlu-M. Ali Cimcoz. İstanbul: Türkiye İş Bankası Kültür Yayınları, 2019.

Rosenthal, Erwin I. J. Ortaçağ'da İslâm Siyaset Düşüncesi. Çev. Ali Çaksu. İstanbul: İz Yayıncılık, 1996.

Sheikh, M. Saeed. Islamic Philosophy. London: The Octagon Press, 1982.

Strauss, Leo. Politika Felsefesi Nedir?. Der. ve çev. Solmaz Zelyüt. İstanbul: Öteki Yayınevi, 2017.

Yıldız, Mustafa. “Yalnızlığın Felsefesi: İbn Bâcce'de Filozofun Yabancılaşması Sorunu". Felsefe Dünyası 55 (2012/1): 99-126. 